\title{
Uptake of Hydrocarbon by Pseudomonas fluorescens (P1) and Pseudomonas putida (K1) Strains in the Presence of Surfactants: A Cell Surface Modification
}

\author{
Ewa Kaczorek • Andrzej Olszanowski
}

Received: 9 December 2009/Accepted: 6 April 2010/Published online: 19 May 2010

(C) The Author(s) 2010. This article is published with open access at Springerlink.com

\begin{abstract}
The objective of this research was the evaluation of the effects of exogenous added surfactants on hydrocarbon biodegradation and on cell surface properties. Crude oil hydrocarbons are often difficult to remove from the environment because of their insolubility in water. The addition of surfactants enhances the removal of hydrocarbons by raising the solubility of these compounds. These surfactants cause them to become more vulnerable to degradation, thereby facilitating transportation across the cell membrane. The obtained results showed that the microorganism consortia of bacteria are useful biological agents within environmental bioremediation. The most effective amongst all, as regards biodegradation, were the consortia of Pseudomonas spp. and Bacillus spp. strains. The results indicated that the natural surfactants (rhamnolipides and saponins) are more effective surfactants in hydrocarbon biodegradation as compared to Triton X-100. The addition of natural surfactants enhanced the removal of hydrocarbon and diesel oil from the environment. Very promising was the use of saponins as a surfactant in hydrocarbon biodegradation. This surfactant significantly increases
\end{abstract}

E. Kaczorek $(\bowtie) \cdot$ A. Olszanowski

Institute of Chemical Technology and Engineering,

Poznan University of Technology,

Pl. M. Skłodowskiej-Curie 2,

60-965 Poznań, Poland

e-mail: ewa.kaczorek@put.poznan.pl the organic compound biodegradation. In the case of those surfactants that could be easily adsorbed on cells of strains (e.g., rhamnolipides), a change of hydrophobicity to ca. $30-40 \%$ was noted. As the final result, an increase in hydrocarbon biodegradation was observed.

Keywords Biodegradation $\cdot$ Hydrocarbon, Hydrophobicity, Pseudomonas $\cdot$ Rhamnolipides . Saponins

\section{Introduction}

The ability to degrade a wide range of xenobiotics by a variety of microorganisms is commonly exploited with bioremediation techniques. Microbes, such as bacteria and yeast, have the ability to metabolize oil-related compounds and therefore are of great importance and also carry with it great expectations regarding the restoration of the natural environment (Atlas 1981; Busscher et al. 1995; Ijah 1998). The optimal biodegradation conditions enable microorganisms to eliminate pollutants quickly. The addition of a surfaceactive compound as an exogenous factor is a crucial step in improving the bioavailability of pollutants and, therefore, could be degraded more efficiently. Busscher et al. (1995) suggested that mutual electrostatic interactions may play a crucial role in the adhesion of microorganisms to hydrocarbon droplets occurring within the water environment. Surfactants can alter 
the features of the outer layers of a cell, known as changes of cell surface hydrophobicity (CSH). Such changes can have a serious impact on the biodegradation processes (Leung et al. 1997; Okerentugba and Ezeronye 2003; Kaczorek et al. 2008). Such modification can simply be due to the adsorption of surfactants on the cell surface, but it is also due to changes in the membrane composition as an effect of surfactant-induced changes. It is also known that some surfactants, due to their toxicity, are able to decrease biodegradation (Volkering et al. 1998). However, surfactants can improve hydrocarbon biodegradation by increasing their solubility in water, promoting emulsification and changing cell surface properties. In the literature, three uptake modes of hydrophobic, poorly soluble hydrocarbon are considered (Gosiami and Singh 1991; Haferburg et al. 1986; Singer and Finnerty 1984). The first is the interfacial accession, which means the direct contact of microorganism cells with hydrophobic hydrocarbon droplets. The second mode is biosurfactant-mediated hydrocarbon uptake, and the third uptake of hydrocarbons dissolved in the aqueous phase.

The aim of the research was to compare the influence of three different surfactants of different quantities on the hydrophobicity of microorganism cells and to the efficiency of hydrocarbon biodegradation. Cell hydrophobicity was determined by using microbial adhesion to the hydrocarbon, a method (MATH test) described by Rosenberg et al. (1980). Rhamnolipides, saponins, and Triton X-100 were chosen as surfactants for the experiments. Our research also focused on the use of bacterial consortia in the bioremediation process. A model mixture of dodecane and hexadecane, as well as diesel oil, was the cause of biodegradation.

\section{Materials and Methods}

\subsection{Microorganisms and Growth Conditions}

Bacterial strains were isolated, by selective enrichment, from soils polluted by crude oil. Samples contaminated were collected from sites in the Polish Carpathian Mountains. The bacteria strains Pseudomonas fluorescens (P1) and Pseudomonas putida K1 were used in the experiments. Strains were identified by biochemical tests and by molecular technique (16S ribosomal DNA). The two bacterial consortia were also prepared: B1 (P. fluorescens P1, P. putida K1, and Pseudomonas spp. strains) and B2 (P. fluorescens P1, P. putida K1, Pseudomonas spp., and Bacillus spp. strains). Culture medium used throughout these studies consisted of the following (in grams per liter): $\mathrm{Na}_{2} \mathrm{HPO}_{4} \cdot 2 \mathrm{H}_{2} \mathrm{O}, 7.0 ; \mathrm{KH}_{2} \mathrm{PO}_{4}, 2.8 ; \mathrm{NaCl}, 0.5$; $\mathrm{NH}_{4} \mathrm{Cl}, 1.0 ; \mathrm{MgSO}_{4} \cdot 7 \mathrm{H}_{2} \mathrm{O}, 0.01 ; \mathrm{FeSO}_{4} \cdot 7 \mathrm{H}_{2} \mathrm{O}$, $0.001 ; \mathrm{MnSO}_{4} \cdot 4 \mathrm{H}_{2} \mathrm{O}, 0.0005 ; \mathrm{ZnCl}_{2}, 0.00064$; $\mathrm{CaCl}_{2} \cdot 6 \mathrm{H}_{2} \mathrm{O}, 0.0001 ; \mathrm{BaCl}_{2}, 0.00006 ; \mathrm{CoSO}_{4} \cdot 7 \mathrm{H}_{2} \mathrm{O}$, 0.000036; $\mathrm{CuSO}_{4} \cdot 5 \mathrm{H}_{2} \mathrm{O}, 0.000036 ; \mathrm{H}_{3} \mathrm{BO}_{3}, 0.00065$; EDTA, 0.001; and $\mathrm{HCl} \mathrm{37 \% ,0.0146} \mathrm{ml} \mathrm{l}^{-1}$. The $\mathrm{pH}$ of the medium was 7.2. For bacteria stock cultures, yeast extract $\left(0.2 \mathrm{~g} \mathrm{l}^{-1}\right)$ was added.

A liquid pre-culture was started by adding a loop full of cells from an agar plate to a 250-ml Erlenmeyer flask containing $50 \mathrm{ml}$ of medium. After about $24 \mathrm{~h}$, a few milliliters (in the range $3-5 \mathrm{ml}$ ) of this liquid culture was used for the inoculation of the final culture to reach an optical density (OD) of ca. 0.1 (which corresponds to $10^{8}$ cells $/ \mathrm{ml}$ ).

\subsection{Hydrocarbon and Surfactants}

Hydrocarbon and other fine chemicals employed in this study were of highest purity grade, produced by Merck (Germany). The following surface-active agents were used: rhamnolipides (Jeneil Biosurfactant Company, USA, JBR 425 - content $25 \%$ of rhamnolipides), saponins (Quillaja bark), and Triton X-100 (Sigma Aldrich, USA). In experiments, we used 1\% concentration of tested surfactants.

\subsection{Microbial Adhesion to Hydrocarbons}

Microbial surface hydrophobicity was assessed by the microbial adhesion to the hydrocarbon method (MATH) described by Rosenberg et al. (1980). The culture was grown on different carbon sources: hydrocarbons (mixture of dodecane and hexadecane), diesel oil, octane, ethylbenzene, glucose, and rhamnose. For these experiments, two parallel systems were examined: carbon source supplemented with the addition of surfactants and surfactants without carbon source. Cells in exponential phase were centrifuged at $7000 \times g$ for $4 \mathrm{~min}$, washed twice with phosphate urea magnesium buffer [containing the following (in grams per liter): $\mathrm{K}_{2} \mathrm{HPO}_{4}, 19.7 ; \mathrm{KH}_{2} \mathrm{PO}_{4}, 7.26$; $\mathrm{H}_{2} \mathrm{NCONH}_{2}, 1.8$; and $\left.\mathrm{MgSO}_{4} \cdot 7 \mathrm{H}_{2} \mathrm{O}, 0.2\right]$, and suspended to fit an OD of ca. $1.0\left(A_{\mathrm{o}}\right.$-initial OD). 
Optical density was measured at $600 \mathrm{~nm}$ on UV-Visible Spectrophotometer Shimadzu. Next, $500 \mu$ l of hexadecane was added to $5 \mathrm{ml}$ of microbial suspension and vortexed for $2 \mathrm{~min}$ with $2500 \mathrm{rpm}$. After $10 \mathrm{~min}$, the OD of the aqueous phase was measured $\left(A_{1}\right)$. The degree of hydrophobicity is calculated as $\left[1-\left(A_{0}-A_{1}\right) / A_{0}\right] \times 100 \%$ [\%]. Each experiment was repeated five times, and values for cell hydrophobicity were calculated as a mean value out of five flasks with a precision of $\pm 4.6 \%$. Cells cultivated on glucose were used as reference cells. When hydrophobicity is between $0 \%$ and $30 \%$, it has been assumed that the cell surface of the microorganism has hydrophilic properties; from $30 \%$ to $40 \%$, the surface has mixed hydrophobic and hydrophilic properties; above $40 \%$, the cell surface of microorganism has hydrophobic properties.

\subsection{Biodegradation Test}

Experiments were performed in Erlenmeyer flask containing $100 \mathrm{ml}$ of mineral salts medium. Samples were incubated at $25^{\circ} \mathrm{C}$ and shaken at $120 \mathrm{rpm}$ for 7 days. A mixture of aliphatic hydrocarbon (dodecane and hexadecane, 1:1 w/w) and diesel oil was used for the biodegradation test. The hydrocarbon concentration in the experiment was $2 \%(\mathrm{w} / \mathrm{v})$. Surfactants were used at $6,30,60,120,150,240$, and $360 \mathrm{mg} / \mathrm{l}$ concentrations. In the case of bacterial consortia, only one amount $(150 \mathrm{mg} / \mathrm{l})$ of surfactants was applied. The hydrocarbon biodegradation was determined using the "Polish standard method for gravimetric determination of hydrocarbon" PN-86 C-04573/01. The hydrocarbon biodegradation was calculated as $\left(S_{\mathrm{o}}-S_{1}\right) / S_{\mathrm{o}} \times 100 \%$ [\%], where $S_{\mathrm{o}}$ is the initial amount of hydrocarbon and $S_{1}$ is the amount of hydrocarbon after biodegradation. After 7 days of biodegradation, the $\mathrm{pH}$ of whole culture broth was decreased to 1 by adding $1 \mathrm{M} \mathrm{HCl}$. After which, the whole broth was centrifuged to separate biomass $(10 \mathrm{~min}$ at $10,000 \times \mathrm{g})$. The residual aqueous phase was subject to double extractions with diethyl ether. The final results are calculated with respect to blank samples (hydrocarbon with medium without microorganisms).

\subsection{Surface Tension}

The surface tension was measured with a du Nouy ring method using the Kruss K 100 tensiometer. The experiments were done at $21 \pm 1^{\circ} \mathrm{C}$. For the equilibrium on the surface, the platinum ring was dipped and kept into the solution for $20 \mathrm{~min}$ before the measurements. Before each set of experiments, the surface tension of water was measured to control the calibration of the tensiometer. A supernatant after separation of bacteria cells was used for the determination of surface tension. The bacteria cells, after separation, were washed by water, and the result of surface tension of the water phase was used to calculate the amount of surfactants adsorbed on bacteria cell surface.

\section{Results and Discussion}

\subsection{The Influence of Surfactants on Cell Hydrophobicity and Hydrocarbon Biodegradation}

The biodegradation of the aliphatic hydrocarbons (dodecane and hexadecane), after 7 days, reached within $30 \%$ for both pure cultures of the Pseudomonas strains. The hydrophobicity of $P$. fluorescens (P1) cells cultivated on several different carbon sources strongly depended on the carbon source characteristics. The pure strain of $P$. fluorescens (P1) has the lowest hydrophobic properties of the cell surface (Table 1). When cultivated on ethylbenzene as a carbon source, the hydrophobicity of the strain was approximately $30 \%$; however, the lowest hydrophobicity was observed when cells were cultivated on glucose, at $8 \%$. P. putida (K1) had different hydrophobic properties. With a strain growth on diesel oil, the hydrophobicity was the highest, at $68 \%$. However, the lowest hydrophobicity was observed when cells were cultivated on glucose, at $10 \%$, whereas in the presence of other carbon sources, P. putida (K1) had more hydrophobic properties (Table 1).

For both strains, the cell hydrophobicity did not depend on temperature. The increase of temperature generated a higher hydrocarbon biodegradation, which was $50 \%$ higher at $35^{\circ} \mathrm{C}$ than at $25^{\circ} \mathrm{C}$ for both strains (Table 2). According to the literature, the most suitable temperature for Pseudomonas growth is in the $25-30^{\circ} \mathrm{C}$ range, and there are no data available regarding biodegradation at higher temperatures.

The addition of surfactants to the system significantly changes the microbial cell surface. The results of hydrophobicity analysis indicated that the modification of microbial cell surface depends on the type of 
Table 1 The influence of different carbon sources on P. fluorescens (P1) and $P$. putida (K1) cell hydrophobicity measured after 7 days of experiments

$O N$ diesel oil

\begin{tabular}{|c|c|c|c|c|c|c|}
\hline \multirow[t]{2}{*}{ Bacteria strain } & \multicolumn{6}{|c|}{ Hydrophobicity (\%) } \\
\hline & Glucose & Rhamnose & $\mathrm{C}_{12}+\mathrm{C}_{16}$ & $\mathrm{ON}$ & Ethylbenzene & Octane \\
\hline P. fluorescens (P1) & $8 \pm 0.9$ & $14 \pm 0.8$ & $20 \pm 3.2$ & $23 \pm 1.2$ & $30 \pm 2.2$ & $21 \pm 1.1$ \\
\hline P. putida $(\mathrm{K} 1)$ & $10 \pm 1.6$ & $33 \pm 2.4$ & $21 \pm 1.7$ & $68 \pm 3.8$ & $34 \pm 2.2$ & $27 \pm 2.1$ \\
\hline
\end{tabular}

surfactant and microorganism genus (Fig. 1a, b). P. putida (K1) strains have hydrophilic properties in systems with surfactants as the only carbon source; the type and quantity of surfactants have no significant influence (Fig. 1b). The addition of hydrocarbon to the system caused the increase of cell hydrophobicity in all tested systems (Fig. 1d). With surfactants of up to $60 \mathrm{mg} / \mathrm{l}$, bacteria hydrophobicity did not significantly change, but the use of higher doses of surfactants caused a decrease in hydrophobicity (Fig. 1c) and an increase in hydrocarbon biodegradation (Fig. 2b). For saponins, the highest hydrocarbon biodegradation $(66 \%)$ was observed with the addition of $120 \mathrm{mg} / \mathrm{l}$ of surfactant. This biodegradation result was nearly $100 \%$ higher than in a system without surfactants. The CMC value of saponins was $87.6 \mathrm{mg} / \mathrm{l}$ (Soeder et al. 1996). In biological systems, the CMC values of surfactants are repeatedly higher, because of the possibility of adsorbing microorganism cells and the biodegradation of surfactants. Liu et al. (1995) recommended that the effect of surfactants could be determined at higher concentrations. Leung et al. (1997) proved that Quillaja saponins have a strong effect on membrane permeabilities. Saponins are considered to form complexes with sterols in plasma membranes of the eukaryotic cell. In plasma membranes of prokaryotes, hopanoids and pentacyclic compounds similar to sterols were found. In many bacterial strains, hopanoids may play important roles in the adjustment of cell membrane permeability and in its adaptation to extreme environmental conditions (Hu et al., 1996).

The highest hydrocarbon (dodecane and hexadecane) biodegradation by $P$. putida $\mathrm{K} 1(60 \%)$ was observed for $150 \mathrm{mg} / \mathrm{l}$ of rhamnolipides. According to Zhang and Miller (1992), the CMC value of rhamnolipides is $40 \mathrm{mg} / \mathrm{l}$. Our study for Aeromonas hydrophila (Kaczorek et al. submitted for publication) indicated that $\mathrm{CMC}$ for rhamnolipides is three times higher in biological systems. Rhamnolipides were collected mainly vertical at the interfacial. Moreover, in the case of rhamnolipides, free-energy adsorption was the least $\left(-\Delta G_{\mathrm{ads}}=45.89 \mathrm{~kJ} / \mathrm{mol}\right)$. This fact suggests that rhamnolipides are surfactants, with the highest tendency of adsorption. For both tested natural surfactants, the hydrophobicity of the cell surface was ca. 30\%, which means that only P. putida K1 has hydrophobichydrophilic properties.

Different results were obtained for $P$. fluorescens P1 (Fig. 1a). This strain has hydrophobic properties $(71-55 \%)$ in systems with natural surfactants (rhamnolipides and saponins), when surfactants of up to $60 \mathrm{mg} / \mathrm{l}$ were added to the solution, whereas with the addition of more than $60 \mathrm{mg} / \mathrm{l}$, the hydrophobicity of bacteria decreases and reaches ca. 30\%. When different concentrations of Triton X-100 were added to the system with $P$. fluorescens $\mathrm{P} 1$, there were no

Table 2 The influence of temperature on bacteria cell hydrophobicity and on hydrocarbon $\left(\mathrm{C}_{12}+\mathrm{C}_{16}\right)$ biodegradation with and without surfactants $(150 \mathrm{mg} / \mathrm{l})$ by P. fluorescens $\mathrm{P} 1$ and $P$. putida $\mathrm{K} 1$

\begin{tabular}{|c|c|c|c|c|c|c|c|c|}
\hline \multirow[t]{3}{*}{ System } & \multicolumn{4}{|c|}{ Hydrophobicity (\%) } & \multicolumn{4}{|c|}{ Hydrocarbon $\left(\mathrm{C}_{12}+\mathrm{C}_{16}\right)$ biodegradation $(\%)$} \\
\hline & \multicolumn{2}{|c|}{ P. fluorescens $\mathrm{P} 1$} & \multicolumn{2}{|c|}{ P. putida $\mathrm{K} 1$} & \multicolumn{2}{|c|}{ P. fluorescens $\mathrm{P} 1$} & \multicolumn{2}{|c|}{ P. putida $\mathrm{K} 1$} \\
\hline & $25^{\circ} \mathrm{C}$ & $35^{\circ} \mathrm{C}$ & $25^{\circ} \mathrm{C}$ & $35^{\circ} \mathrm{C}$ & $25^{\circ} \mathrm{C}$ & $35^{\circ} \mathrm{C}$ & $25^{\circ} \mathrm{C}$ & $35^{\circ} \mathrm{C}$ \\
\hline $\mathrm{C}_{12}+\mathrm{C}_{16}$ & $20 \pm 3.2$ & $20 \pm 2.1$ & $21 \pm 2.8$ & $21 \pm 1.8$ & $30 \pm 2.1$ & $47 \pm 1.4$ & $31 \pm 2.3$ & $45 \pm 2.4$ \\
\hline Rhamnolipides $+\mathrm{C}_{12}+\mathrm{C}_{16}$ & $39 \pm 2.9$ & $38 \pm 1.6$ & $32 \pm 2.5$ & $32 \pm 1.2$ & $48 \pm 3.2$ & $65 \pm 2.3$ & $44 \pm 2.9$ & $60 \pm 2.6$ \\
\hline Saponins $+\mathrm{C}_{12}+\mathrm{C}_{16}$ & $37 \pm 1.9$ & $38 \pm 2.2$ & $26 \pm 2.1$ & $25 \pm 1.7$ & $43 \pm 3.1$ & $61 \pm 2.7$ & $60 \pm 3.1$ & $71 \pm 3.3$ \\
\hline
\end{tabular}


a

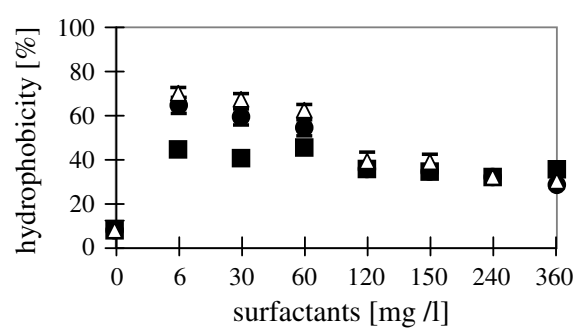

C

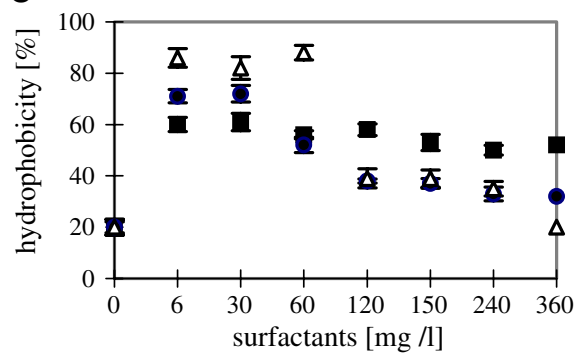

Fig. 1 Effect of surfactant concentration on cell hydrophobicity (the process was carried out in a mineral salts medium over 7 days); hydrophobicity was measured by MATH methods; surfactants were the only carbon source: P. fluorescens P1 (a)

significant changes in hydrophobicity observed. The addition of all tested surfactants to the system with hydrocarbons (mixture of dodecane and hexadecane) effectively increased the hydrophobic properties of $P$. fluorescens P1 (Fig. 1c).

The results of surface tension suggest that substantial amounts of exogenously added surfactants were collected at the external layers of microorganisms (Table 3 ). The amount of surfactants adsorbed at the cell surface depends on the initial surfactant concentration; therefore, the increase of hydrocarbon biodegradation is also probably connected with surfactant adsorption and the resulting bacteria hydrophobicity changes.

The ability of surfactant adsorption at the cell surface is in the following order: rhamnolipides $>$ saponins $>$ Triton X-100 (Table 3).

Bacterial adhesion is one of the first steps of a biofilm formation. $\mathrm{CSH}$ has been considered as an important factor in the stability of microbial aggregates (Liu et al. 2004). According to Li et al. (2006), extracellular polymeric substances play a significant role in bacterial aggregation. Absolom et al. (1983) and Bos et al. (1999) noted that hydrophobic strains adhere better to hydrophobic substrate, while hydrophilic strains have a thermodynamic preference for hydrophilic substrata. Our research indicated that the

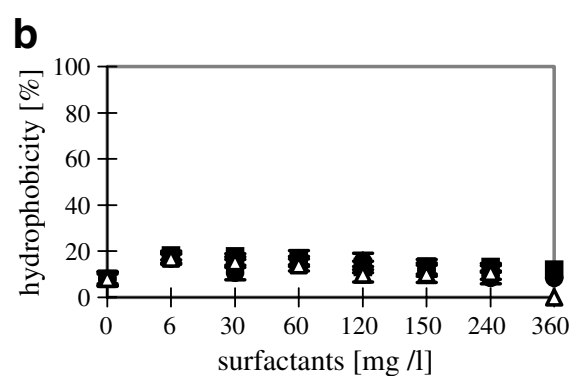

d

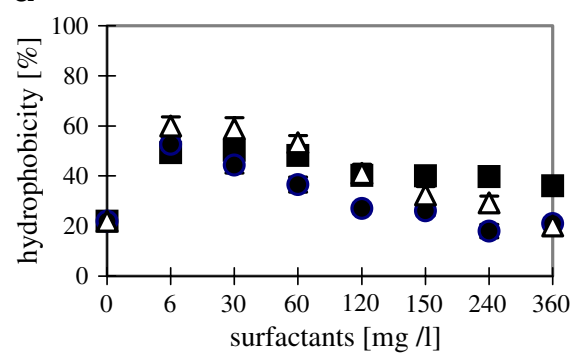

and P. putida $\mathrm{K} 1$ (b); system surfactant-hydrocarbon (model mixture, dodecane, and hexadecane) was the carbon source: $P$. fluorescens $\mathrm{P} 1$ (c) and P. putida $\mathrm{K} 1$ (d). Filled square Triton $\mathrm{X}$ 100, filled circle saponins, open triangle rhamnolipides

best biodegradation of hydrocarbons was observed when cells had hydrophilic-hydrophobic properties (hydrophobicity was approximately 30\%). According to Cserhati et al. (2002), anionic surfactants show marked biological activity either by binding to various bioactive macromolecules or by being inserted into various cell fragments, that is, phospholipid membranes causing malfunction. Rhamnolipides were particularly effective for cells with low initial hydrophobicity. The addition of biosurfactant causes an increase of CSH (Zhang and Miller 1994). In contrast, microorganisms with a high initial cell hydrophobicity were unaffected by the addition of rhamnolipides in terms of cell hydrophobicity changes (for four P. aeruginosa strains).

The addition of different amounts of synthetic surfactant Triton X-100 does not significantly affect the hydrophobicity of cells of both types of bacteria. The highest biodegradation (40\%) by P. fluorescens (P1) was observed with the use of $60 \mathrm{mg} / \mathrm{l}$ of this surfactant. When P. putida (K1) was used, the hydrocarbon biodegradation was $48 \%$ (for $150 \mathrm{mg} / \mathrm{l}$ ). According to Liu et al. (1995), Triton X-100 did not inhibit the growth of the gram-negative Escherichia coli strain on glucose at concentrations above CMC. They did not observe Triton X-100 biodegradation, while 

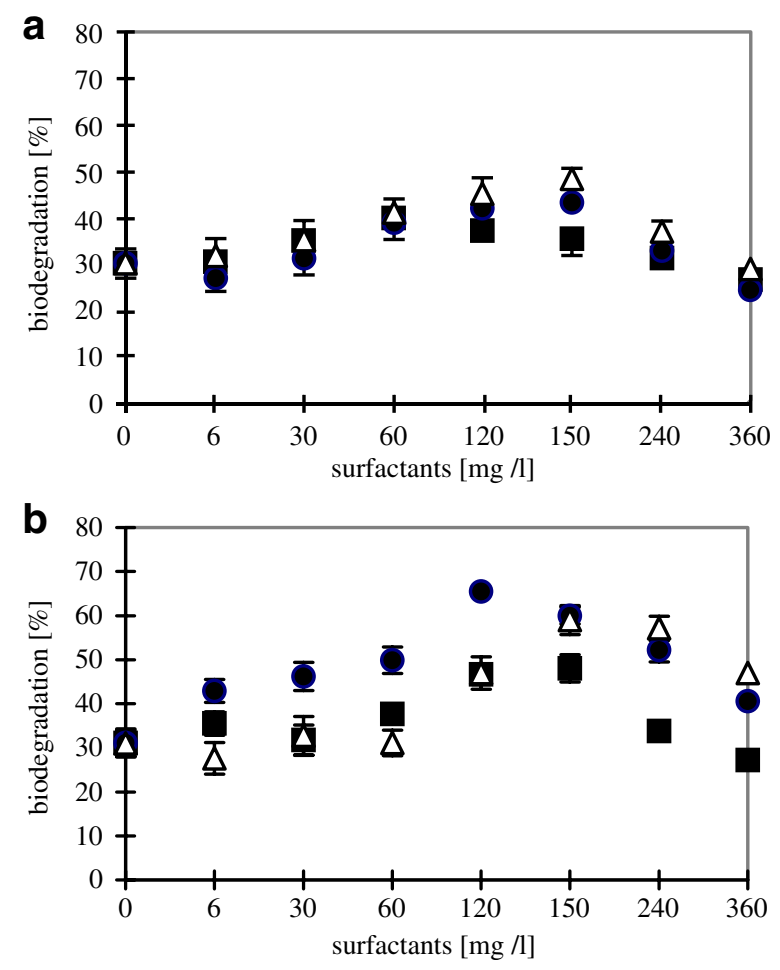

Fig. 2 Effect of surfactant concentration on hydrocarbon (model mixture, dodecane, and hexadecane) biodegradation (the process was carried out in a mineral salts medium over 7 days); P. fluorescens $\mathrm{P} 1$ (a), P. putida $\mathrm{K} 1$ (b). Filled square Triton X-100, filled circle saponins, open triangle rhamnolipides. Controls: for $3 \%$ to $4.5 \%$

naphthalene was degraded in the presence of Triton X-100 with naphthalene. However, Allen et al. (1999) confirmed that this non-ionic surfactant can prove quite the opposite effects on the biotransformation of PAHs.
Our results showed that natural surfactants such as rhamnolipides and saponins are more effective in the biodegradation of hydrocarbons and diesel oil than synthetic Triton X-100 (Fig. 3). Rhamnolipides increase the $\mathrm{CSH}$ and diesel oil biodegradation (62\%) only for the P. fluorescens strain. In the case of $P$. putida, the biodegradation of diesel oil was comparable to systems without biosurfactants, but the $\mathrm{CSH}$ was significantly different. In systems without surfactants, strains have hydrophobic properties. The addition of rhamnolipides caused a decrease in the hydrophobicity. For P. putida, an increase in biodegradation was observed after the addition of saponins to the system $(76 \%)$. However, there were no significant changes in cell hydrophobicity observed after the addition of saponins.

\subsection{Diesel Oil Biodegradation by Bacterial Consortia}

The study of hydrophobicity and diesel oil biodegradation with two bacterial consortia B1 and B2 was also carried out (Table 4). B2 consortia contained bacteria from Pseudomonas and Bacillus. Grampositive bacteria are present in environmental soil samples. We studied the influence of the Bacillus genus when added to gram-negative consortium on diesel oil biodegradation. The obtained results indicated that the B2 consortia could efficiently degrade the diesel oil up to $57 \%$. The addition of natural surfactants has a great influence on diesel oil biodegradation. These surfactants cause micelle formation and the uptake of pseudosolubilized hydrocarbon droplets by microorganisms. With the

Table 3 Surface tension of supernatant, obtained after washed bacteria cells increasing in surfactant solution (P. fluorescens P1)

\begin{tabular}{|c|c|c|c|c|c|c|}
\hline \multirow{3}{*}{$\begin{array}{l}\text { Concentration of } \\
\text { surfactant }(\mathrm{mg} / \mathrm{l})\end{array}$} & \multicolumn{6}{|c|}{ Surface tension $(\mathrm{mN} / \mathrm{m})$ and amount of adsorbed surfactant $(\mathrm{mM})$} \\
\hline & \multicolumn{2}{|c|}{ Rhamnolipides } & \multicolumn{2}{|l|}{ Saponins } & \multicolumn{2}{|c|}{ Triton $\mathrm{X}-100$} \\
\hline & $\begin{array}{l}\text { Surface } \\
\text { tension } \\
(\mathrm{mN} / \mathrm{m})\end{array}$ & $\begin{array}{l}\text { Amount of adsorbed } \\
\text { surfactant }(\mathrm{mM})\end{array}$ & $\begin{array}{l}\text { Surface } \\
\text { tension } \\
(\mathrm{mN} / \mathrm{m})\end{array}$ & $\begin{array}{l}\text { Amount of adsorbed } \\
\text { surfactant }(\mathrm{mM})\end{array}$ & $\begin{array}{l}\text { Surface } \\
\text { tension } \\
(\mathrm{mN} / \mathrm{m})\end{array}$ & $\begin{array}{l}\text { Amount of adsorbed } \\
\text { surfactant }(\mathrm{mM})\end{array}$ \\
\hline 30 & $\begin{array}{l}33.0 \pm \\
0.08\end{array}$ & $0.169 \pm 0.007$ & $\begin{array}{l}57.5 \pm \\
0.47\end{array}$ & $0.037 \pm 0.006$ & $\begin{array}{l}47.4 \pm \\
0.10\end{array}$ & $0.0127 \pm 0.005$ \\
\hline 60 & $\begin{array}{l}30.8 \pm \\
0.12\end{array}$ & $0.399 \pm 0.006$ & $\begin{array}{l}50.7 \pm \\
0.32\end{array}$ & $0.087 \pm 0.006$ & $\begin{array}{l}42.7 \pm \\
0.42\end{array}$ & $0.04 \pm 0.003$ \\
\hline 150 & $\begin{array}{l}29.9 \pm \\
0.18\end{array}$ & $0.61 \pm 0.009$ & $\begin{array}{l}49.2 \pm \\
0.25\end{array}$ & $0.09 \pm 0.001$ & $\begin{array}{l}41.2 \pm \\
0.31\end{array}$ & $0.06 \pm 0.001$ \\
\hline
\end{tabular}

Control surface tension: suspension with bacteria cell, $69.9 \pm 0.05 \mathrm{mN} / \mathrm{m}$; water, $71.25 \pm 0.09 \mathrm{mN} / \mathrm{m}$ 
Fig. 3 Surfactants' influence on diesel oil biodegradation and cell membrane modification after 7 days by P. fluorescens (P1) and $P$. putida (K1) strains: 1 no surfactant, 2 rhamnolipides, 3 saponins, 4 Triton X-100. Quantity of surfactants$150 \mathrm{mg} / 1$

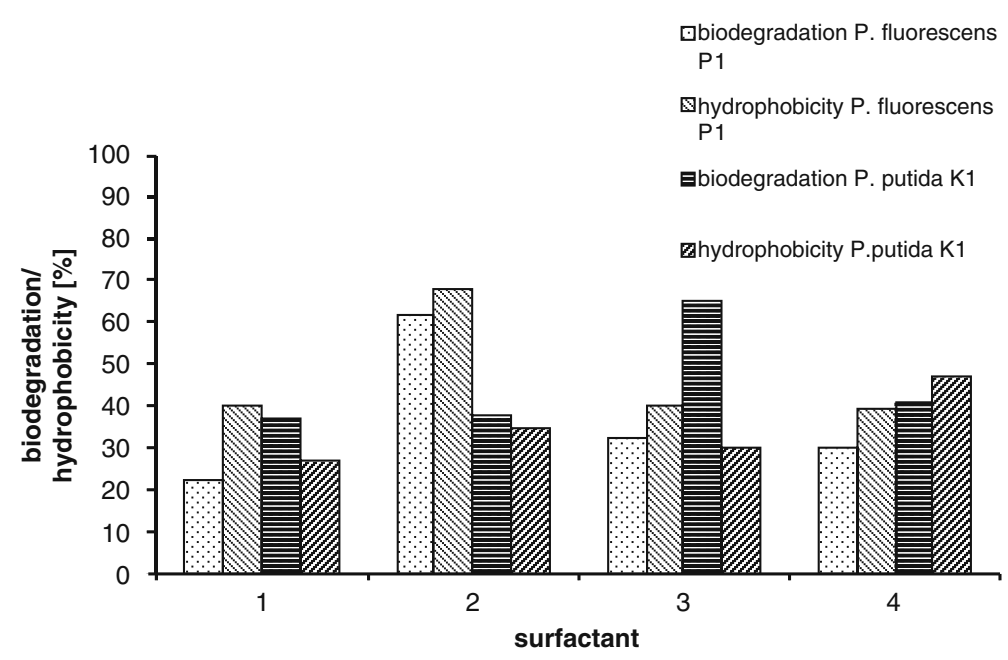

presence of rhamnolipides or saponins in the system, the diesel oil biodegradation reached ca. 92\%. Hydrophobicity analyses show a significant decrease of this parameter in relation to the initial value, causing high hydrocarbon biodegradation. The cell surface of microorganisms became clearly hydrophilic after the addition of surfactants. The hydrocarbon system B2 consortia had a higher hydrophobicity $(89 \%)$ than the B1 consortia $(46 \%)$. The addition of either natural surfactant (rhamnolipides or saponins) significantly decreased the hydrophobicity and an increase of diesel oil biodegradation was observed, whereas insignificant changes of hydrophobicity were observed with the addition of Triton X-100. Hydro- carbon biodegradation in this system was comparable with the system without surfactants.

Rahman et al. (2002) showed that the best crude oil biodegradation was observed in the system with bacterial consortia than with the individual pure bacteria strains. Their mixed bacterial consortia could carry out a maximum of $78 \%$ of crude oil biodegradation after 20 days. Our obtained results indicated that natural surfactants could significantly increase the diesel oil biodegradation. For both consortia, saponins were the best surfactants; biodegradation significantly increased after their addition. The addition of rhamnolipides biosurfactant had a positive effect only with the consortia that consisted of Pseudomonas spp. and

Table 4 Hydrophobicity of bacteria cell surface and diesel oil biodegradation by two bacterial consortia: B1 (P. fluorescens P1, P. putida K1, and Pseudomonas spp.) and B2 (P. fluorescens P1, P. putida K1, Pseudomonas spp., and Bacillus spp.)

\begin{tabular}{llc}
\hline System & Biodegradation (\%) & Hydrophobicity (\%) \\
& Consortium B1 (P. fluorescens P1, P. putida K1, and Pseudomonas spp.) \\
Diesel oil & $31.8 \pm 1.8$ & $46.2 \pm 1.4$ \\
Diesel oil+rhamnolipides & $45.7 \pm 1.0$ & $37.3 \pm 1.9$ \\
Diesel oil+saponins & $78.3 \pm 2.3$ & $26.8 \pm 1.1$ \\
Diesel oil+Triton X-100 & $46.2 \pm 1.4$ & $39.8 \pm 2.8$ \\
& Biodegradation (\%) Hydrophobicity (\%) \\
& Consortium B2 (P. fluorescens P1, P. putida K1, Pseudomonas spp., and Bacillus spp.) \\
Diesel oil & $56.8 \pm 0.9$ & $88.9 \pm 2.6$ \\
Diesel oil+rhamnolipides & $94.4 \pm 2.5$ & $21.7 \pm 3.5$ \\
Diesel oil+saponins & $89.6 \pm 1.8$ & $39.5 \pm 2.1$ \\
Diesel oil+Triton X-100 & $56.2 \pm 1.8$ & $77.2 \pm 1.9$ \\
\hline
\end{tabular}

Time of biodegradation, 7 days; concentration of surfactants, $150 \mathrm{mg} / 1$ 
Bacillus spp. (B2). For B1 consortia consisting of only Pseudomonas spp. strains, a positive influence of rhamnolipides was not observed. The presence of Bacillus spp. in consortia caused a significant increase in hydrocarbon biodegradation in the rhamnolipides system. According to Zhang and Miller (1994), mutual attraction between biosurfactant and microbial cells can lead to an increase in cell hydrophobicity, and therefore, cells have a better contact with the hydrophobic substrate and finally a higher biodegradation could be achieved. Our hydrophobicity results for consortia B2 suggest rather that the addition of rhamnolipides to Bacillus and Pseudomonas consortia decreased the hydrophobicity of microorganism systems. For all tested microorganism consortia, a favorable influence of Triton X-100 was not observed. However, Mukherji and Mohanty (2007) suggested that Triton X-100 can significantly enhance the rate and extent of diesel degradation by Exiguobacterium aurantiacum and Burkholderia cepacia. They obtained these results when Triton X-100 concentration was twice the CMC. Tsubata et al. (1998) suggested that Triton X100 rather changes cell growth of microorganisms in the presence of high concentration of organic compounds. This surfactant decreases the degree of aggregation and improves growth.

Lower diesel oil biodegradation was observed when Triton X-100 was used (Table 4). The use of rhamnolipides or saponins seems to be a better bioremediation approach to environmental protection. These natural surfactants are easily biodegraded and therefore friendlier to the natural environment than Triton X-100. Moreover, we observed the positive effect of Bacillus genus on hydrocarbon biodegradation.

\section{Conclusion}

A very important matter is the selection of microorganisms to create a biologically active microorganism consortia, which could efficiently degrade the crude oil components. Our results indicated that hydrocarbon or diesel oil could be better biodegraded by bacterial consortia consisting of Pseudomonas spp. and Bacillus spp. strains than only Pseudomonas spp. The increase of the biodegradation process could be enhanced by the addition of natural surfactants.

The addition of surfactants to the system changed crucial parameters and cell surface properties of micro- organisms. It is especially visible in the case of rhamnolipides, which are significantly adsorbed on the cell surface. A higher initial hydrophobicity of microorganisms does not guarantee relevant results in the hydrophobic compound degradation. Our results indicated that the best results of hydrocarbon biodegradation occur when the hydrophobicity for the pure strain is ca. $30-40 \%$ (hydrophobic and hydrophilic properties), especially when the surfactant could be easily adsorbed on the cell surface, for example, rhamnolipides. The addition of surfactant could change not only cell properties but also membrane permeability. Very promising is the use of saponins in hydrocarbon and diesel oil biodegradations. Saponins influence the permeability of cell membrane without clear hydrophobicity changes. These interactions depend on the type and concentration of surfactants and the genus of the microorganism. Therefore, the initial experiment for the selection of the optimal conditions of hydrocarbon bioremediation is very important. The use of consortia of different organisms enables a better result, but sometimes lower hydrocarbon degradation could be observed than for pure strains. The selection of the microorganism mixture is very important in the bioremediation process.

Acknowledgements This study was funded by the Polish Ministry of Science and Higher Education (GR 32/0897/2008).

Open Access This article is distributed under the terms of the Creative Commons Attribution Noncommercial License which permits any noncommercial use, distribution, and reproduction in any medium, provided the original author(s) and source are credited.

\section{References}

Absolom, D. R., Lamberti, F. V., Policova, Z., Zingg, W., Van Oss, C. J., \& Neumann, A. W. (1983). Surface thermodynamics of bacterial adhesion. Applied and Environmental Microbiology, 46, 90-97.

Allen, C. C. R., Boyd, D. R., Hempenstall, F., Larkin, M. J., \& Sharma, N. D. (1999). Contrasting effects of a nonionic surfactant on the biotransformation of polycyclic aromatic hydrocarbons to cis-dihydrodiols by soil bacteria. Applied and Environmental Microbiology, 65, 1335-1339.

Atlas, R. M. (1981). Microbial degradation of petroleum hydrocarbons; an environmental perspective. Microbiological Reviews, 45, 180-209.

Bos, R., van der Mei, H. C., \& Busscher, H. J. (1999). Physicochemistry of initial microbial adhesive interactions-Its mechanism and methods to study. FEMS Microbiology Letters, 9, 29-33. 
Busscher, H. J., van de Belt-Gritter, B., \& van der Mei, H. C. (1995). Implications of microbial adhesion to hydrocarbons for evaluating cell surface hydrophobicity: 1 . Zeta potentials of hydrocarbon droplets. Colloids and Surfaces $B, 5,111-116$.

Cserhati, T., Forgacs, E., \& Oros, G. (2002). Biological activity and environmental impact of anionic surfactants. Environment International, 28, 337-348.

Gosiami, P., \& Singh, H. D. (1991). Different modes of hydrocarbon uptake by two Pseudomonas species. Biotechnology and Bioengineering, 37, 1-11.

Haferburg, D., Hommel, R., Claus, R., \& Kleber, H. P. (1986). Extracellular microbial lipids as biosurfactants. Advances in Biochemical Engineering/Biotechnology, 33, 53-93.

Hu, M., Konoki, K., \& Tachibana, K. (1996). Cholesterolindependent membrane disruption caused by triterpenoid saponins. Biochimica et Biophysica Acta, 1299, 252-258.

Ijah, U. J. J. (1998). Studies on relative capabilities of bacterial and yeast isolates from tropical soil in degrading crude oil. Waste Management, 18, 293-299.

Kaczorek, E., Chrzanowski, Ł., Pijanowska, A., \& Olszanowski, A. (2008). Yeast and bacteria cell hydrophobicity and hydrocarbon biodegradation in the presence of natural surfactants: rhamnolipides and saponins. Bioresource Technology, 99, 4285-4291.

Kaczorek, E., Urbanowicz, M., \& Olszanowski, A. The influence of surfactants on cell surface properties of Aeromonas hydrophila during diesel oil biodegradation. Manuscript submitted for publication.

Leung, Y. M., Ou, Y. J., Kwan, C. Y., \& Loh, T. T. (1997). Specific interaction between tetrandrine and Quillaja saponins in promoting permeabilization of plasma membrane in human leukemic HL-60 cell. Biochimica et Biophysica Acta, 1325, 318-328.

Li, Z. H., Kuba, T., \& Kusuda, T. (2006). The influence of starvation phase on the properties and the development of aerobic granules. Enzyme and Microbial Technology, 38, 670-674.

Liu, Y., Yang, S. F., Li, Y., Xu, H., Qin, L., \& Tay, J.-H. (2004). The influence of cell and substratum surface hydrophobicities on microbial attachment. Journal of Biotechnology, 110, 251-256.

Liu, Z., Jacobson, A. M., \& Luthy, R. G. (1995). Biodegradation of naphthalene in aqueous non-ionic surfactant system. Applied and Environmental Microbiology, 61, 145-151.
Mukherji, S., \& Mohanty, G. (2007). Effect of an emulsifying surfactant on diesel degradation by cultures exhibiting inducible cell surface hydrophobicity. Journal of Chemical Technology and Biotechnology, 82, 1004-1011.

Okerentugba, P., \& Ezeronye, O. (2003). Petroleum degrading potentials of single and mixed microbial cultures isolated from rivers and refinery effluent in Nigeria. African Journal of Biotechnology, 2, 288-292.

PN-86 C-04573/01 — Polish standard method for gravimetric determination of hydrocarbon (1986).

Rahman, K. S. M., Thahira-Rahman, J., Lakshmanaperumalsamy, P., \& Banat, I. M. (2002). Towards efficient crude oil degradation by mixed bacterial consortium. Bioresource Technology, 85, 257-261.

Rosenberg, M., Gutnick, D., \& Rosenberg, E. (1980). Adherence of bacteria to hydrocarbons: A simple method for measuring cell-surface hydrophobicity. FEMS Microbiology Letters, 9, 29-33.

Singer, M. E., \& Finnerty, W. R. (1984). Microbial metabolism of straight-chain and branched alkanes. In R. M. Atlas (Ed.), Microbial metabolism of straight-chain and branched alkanes (pp. 1-60). New York: Macmillan Publishing Company.

Soeder, C. J., Papaderos, A., Kleespies, M., Kneifel, H., Haegel, F. H., \& Webb, L. (1996). Influence of phytogenic surfactants (quillaya saponins and soya lecithin) on bio-elimination of phenanthrene and fluorantheneby three bacteria. Applied Microbiology and Biotechnology, 44, 654-659.

Tsubata, T., Tezuka, T., \& Kurane, R. (1998). Influence of Triton X-100 on growth of Pseudomonas putida No. 69-3, an $n$-heptanol-tolerant variant of an organic solventsensitive bacterium, Pseudomonas putida No. 69. Clean Products and Processes, 1, 61-65.

Volkering, F., Breure, A. M., \& Rulkens, W. H. (1998). Microbiological aspects of surfactants use for biological soil remediation. Biodegradation, 8, 401-417.

Zhang, Y., \& Miller, R. M. (1992). Enhanced octadecane dispersion and biodegradation by a Pseudomonas rhamnolipides surfactant (biosurfactant). Applied and Environmental Microbiology, 58, 3276-3282.

Zhang, Y., \& Miller, R. M. (1994). Effect of a Pseudomonas rhamnolipides biosurfactant on cell hydrophobicity and biodegradation of octadecane. Applied and Environmental Microbiology, 60, 2101-2106. 